\title{
EDU-CONNECT AND SOUTHERN TAIWAN'S DREAMS OF AN IMAGINED REGION
}

\author{
Brian Uy Doce $\boldsymbol{D}^{a}$
}

\begin{abstract}
In 2016, the island-nation of Taiwan launched its New Southbound Policy (NSBP) to improve its cooperation efforts to Southeast Asian countries. However, even prior to the "look-south" attitude, a private organisation in Southern Taiwan has already initiated their own partnership efforts to Southeast Asian counterparts a decade before. Named as the Edu-Connect Southeast Asia Association, the organisation aims to create an integrated region by starting with the Philippines through the employment of city learning tours to Kaohsiung City to promote academic and business linkages. This commentary offers an appraisal about its activities by attempting to locate them in the extant literature. While regionalization attempts through education is no longer a novel approach, the Edu-Connect faces a number of challenges and opportunities in its engagement with the Philippines higher educational sector particularly in the following issues, namely, the unique status of its institutional partners in the Philippines, the potential of universities to emerge as game-changers in international affairs, the tendency of polarizing views dictated by the dichotomy of classifying countries as developed and developing, power asymmetries between Southern Taiwan and Philippine universities, and certain issues on its social entrepreneurship operations.
\end{abstract}

Keywords: Regionalism, Taiwan, Educational Cooperation, Non-state Actors, Global Partnerships

\section{INTRODUCTION}

While the island-nation of Taiwan launched its New Southbound Policy (NSBP) in 2016 that promoted a "look south" attitude towards its domestic businesses and other stakeholders, an organisation had already undertaken the same initiative prior to the implementation of the aforementioned foreign policy. This organisation is the EduConnect Southeast Asia Association (hereinafter referred to as "Edu-Connect") - a university alliance based in Kaohsiung City. With the NSBP's recalibrated approach of economic integration with Southeast Asia, the independent efforts of the Edu-Connect pursued a similar stance as it has frequently singled-out one of its objectives as creating an integrated region between Southern Taiwanese local governments and Southeast Asian states - with the Philippines as its piloted platform ${ }^{\mathrm{i}}$.

\footnotetext{
a Brian Uy Doce (brian.doce@uap.asia) is a Lecturer, Political Economy Program, the University of Asia \& the Pacific (UA\&P), Pasig City, the Philippines.
} 
While the main core of the definition of regionalisation lies in transforming a group of countries into a significant economic or political bloc (Heywood, 2011), the process of regionalisation has attributed a number of agents such as the role of individual States (Väyrynen, 2003), selected political elite (Solidum, 2018), non-state actors performing transnational operations (Söderbaum \& Shaw, 2003), and even up to the efforts of grassroots movements (Tadem, et al., 2020). As regionalisation efforts of EduConnect are plausible to be located in the extant literature of regionalism, its efforts in creating an artificial consciousness of belonging to a single bloc between Southern Taiwan and Southeast Asia are also compatible since preceding works on the matter noted the fluid and overlapping nature of regional-building attempts (see Heywood, 2011).

\section{EDU-CONNECT AND ITS REGIONAL AGENCY}

The Edu-Connect is a multisectoral civil society organisation based in Kaohsiung City, one of Taiwan's emerging global cities outside its capital (Lim \& Liu, 2018). Its members are primarily composed of universities outside Taipei City, particularly those higher educational institutions located among local governments southward. However, a number of businesses, particularly newly established micro-, small- and medium- scale enterprises (MSMEs), also actively participate in its activities since the organisation promotes its Industry-City-University-Entrepreneur (ICUE) linkage model of development (News Insider, 2020). Since its foundation in 2016, it has successfully reached around 50 Philippine universities for purposes of internationalisation as well as academic and development partnerships (MECO/Edu-Connect Training Network in Asia, What We Do, n.d.).

Since the Edu-Connect is primarily composed of higher educational institutions, its edge against other regionalisation attempts is its focus and investment in educational cooperation by particularly contributing to the global knowledge economy. Historically speaking, such regionalisation attempt was previously pursued by Central American higher education stakeholders through the creation of the Central American Council for Higher Education in 1948 (Dabène, 2009). Although this Latin American experiment failed, the Edu-Connect's regional context and circumstances are totally different compared to its precedent. First, the educational integration attempt in Latin America took place during the pre-text of the Cold War in which regional environment was mired with political instability and poverty. On the contrary, this situation is absent in Taiwanese higher education since the sector operates with academic freedom and considerable governmental support. In addition, Taiwanese society also enjoys a relatively higher standard of living and quality of life compared to their Latin American counterparts. Second, the Edu-Connect pushes educational cooperation beyond official university visits and benchmarking missions by organising so-called "City Learning Tours" where the Edu-Connect arranges a thematic itinerary for visiting academics looking for their academic counterparts in Southern Taiwan cities. In this itinerary, destination stops are considered holistic as they include visits not only to targeted partner universities, but also to pertinent local government offices, research institutes, and firms. Through these city learning tours, the Edu-Connect advertises the success of ICUE 
linkages in Southern Taiwan cities hoping to be imitated by Southeast Asian developing countries.

As mentioned, the Edu-Connect designated the Philippines as its pilot partner in its activities. Its partnership efforts with the Southeast Asian country is compartmentalised into two major projects. One is called the Training Network in Asia (TNA) - a startup project with the Manila Economic and Cultural Office (MECO), the Philippine representative office in Taiwan. The other one is a company currently in the incubation period which aims to bring young Filipino university graduates to teach practical English language skills to Taiwanese professionals in exchange for a decent honorarium, Chinese language learning, and entrepreneurship training. Upon completion of their tenure, these future teachers are required to go back to the Philippines and commence their own development projects in their respective provinces ${ }^{2}$.

\section{ISSUES AND PROSPECTS}

Within five years of its existence, the Edu-Connect had managed to transform different obstacles into opportunities to pursue its objectives in the Philippines. While the Philippines officially adheres to the One China Policy (Geducos, 2020), the Edu-Connect was successful in engaging a number of public and private sector bodies such as the Mandaluyong City Government, the Manila Economic and Cultural Office (MECO), the Taipei Economic and Cultural Office in the Philippines (TECO), the Asian Development Bank (ADB), the University of the Philippines - System, and the Philippine Association of State Universities and Colleges (PASUC) (Dabu, 2019). Foremost among these efforts was the Edu-Connect's collaboration with MECO through the institutionalisation of the TNA - a project aiming to bring Filipino academics, entrepreneurs, experts, and industry leaders to visit Southern Taiwan for purposes of academic and business partnerships. The success of this pioneering effort can be attributed to the special status enjoyed by MECO despite the restrictions imposed by the Philippine's recognition of One China Policy. Since MECO enjoys a sui generis status per the Philippine Supreme Court mandating the office to be registered as a private enterprise (Perez, 2014), such situation enables the office to pursue innovative business projects and collaborations as long as it is compliant to the provisions of the One China Policy.

Meanwhile, by looking at the potential of the Edu-Connect by pursuing its aspirations of an integrated region between Southern Taiwan and Southeast Asia, the key role played by its university members serves as a reinforcement of the capability of nonstate actors to influence international affairs. As lamented by various scholars, international relations scholarship has been confined in its state-centric orientation (Lacher, 2003). However, due to the rapid changes brought by globalisation, several nontraditional players had commenced in participating in the messy status of international affairs, including universities. At present, the extant literature presents that the contemporary role of universities in global affairs has been evident in their internationalisation activities where observers speculated that these domestic institutions are capable of wielding soft power (Knight, 2017), and alliance-type behaviour through regional networks and consortia (Tadaki \& Tremewan, 2013). 
On the other hand, as the Edu-Connect focuses on the promotion of city learning tours in Southern Taiwan to interested Filipino clients, the organisation is yet to be examined if it also follows the unfortunate trajectory of the study visits of Global North schools to Global South partners which were observed as actions that perpetuates "othering" and colonial stereotypes (Martin \& Griffiths, 2012). Although Taiwan does not have a historical record of imperialism and colonialism, the fact that it is one of the developed nations in the East Asian region presents a tendency to emphasise the disparity in terms of material resources and academic advancement between Southern Taiwan and Philippine universities.

Furthermore, corollary to the North-South premise of the previous premise, another challenge for the Edu-Connect is to dispel the "asymmetrical relations in university internationalization" (Hagenmeier, 2017). One avenue to respond to this aspect is the very fact that the reason behind the existence of this university alliance in Southern Taiwan is due the perceived elitism practiced by universities located in northern Taiwan particularly in Taipei ${ }^{3}$. Looking at the "everyday" perspective in the social sciences (Hobson \& Seabrooke, 2007), the performance of these Southern Taiwan universities of ordinary actions expected from an educational institution such as participation in educational consortia and internationalisation efforts to universities abroad serves as covert actions to resist the hegemonic tendencies and impression possessed by Taipeibased universities.

Lastly, among its other Asian counterparts engaging the Philippine higher education, the Edu-Connect's edge is its emphasis and practice of ICUE linkages. A concrete manifestation of this claim is the networking infrastructure it established through its partnership with the Kindness Hotel Chain. Through this collaboration, spaces and facilities for meetings and networking were opened by Kindness Hotel to accommodate Filipino visitors, namely, the UP and PASUC Fellowship Centres, and the University Partnership Guesthouse. These facilities offer discounted rates for Filipino delegations to defray the costs of their travel and visits to Southern Taiwan cities. (MECO/Edu-Connect Training Network in Asia, 2019). These efforts to assist Filipino delegations are truly beneficial especially for Philippine public universities struggling to catch up with the present race towards internationalisation efforts and goals to land in international university rankings.

\section{CONCLUSION}

Despite the consistent promotion and reach-out of the Edu-Connect member institutions to their targeted Philippine counterparts, activities were halted because of the COVID-19 pandemic as both Taiwan and the Philippines imposed their respective lockdowns to stem the transmission of the novel coronavirus in the local populace. Thus, at present, the EduConnect faces a major challenge in its objective since the organisation previously relied in the mobility of faculty members and students to sustain the operations of the observed regional integration efforts. Not until a vaccine or drug has become available to counter 
the pandemic, international travel is constrained and will no longer be like it was before. As various educational cooperation regimes and efforts grapple to find a way to survive this crisis, the Edu-Connect also needs to devise alternative flexible collaboration plans with its Philippine partners if it is serious in delivering its regional aspirations.

\section{Notes}

i In the official website of one of Edu-Connect's startup projects, the vision explicitly states its objective of, "An integrated region between the Filipinos and Taiwanese people inspired by the power of education as a weapon to eradicate poverty and deliver Asian inclusive development" (MECO/Edu-Connect Training Network in Asia, Vision and Mission, n.d.)".

2 The claims presented in this paragraph were based on the author's experience of working as the first Project Liaison Officer of the aforementioned start-up project called "Training Network in Asia" of the Edu-Connect and MECO.

3 There are various reasons behind this phenomenon. One reason is due to students' preference to go to Taipei because of its urban landscape (Chen, Hsu, \& Liu, 2017). Another reason is the "mercy killing" practice of terminating university operations by the Ministry of Education as outside Taipei universities struggle to recruit students due to Taiwan's on-going demographic winter (Huang, 2019).

\section{REFERENCES}

Heywood, A. (2011). Global Politics. New York: Palgrave Macmillan.

Solidum, E. (2018). Towards a Southeast Asian Community. In J. V. Tigno, TwentiethCentury Philippine Political Thinkers (pp. 248-292). Quezon City: The University of the Philippines Press.

Tadem, E. C., Hapal, K. F., Papa, V. B., Aban, A. P., Candelaria, N. P., Tabiola, H. B., et al. (2020, May 19). UP CIDS DISCUSSION PAPER 2020-04: Deepening Solidarities Beyond Borders Among Southeast Asian Peoples: A Vision for a Peoples' Alternative Regional Integration.

MECO/Edu-Connect Training Network in Asia. (n.d.). Vision and Mission. Retrieved from MECO/Edu-Connect Training Network in Asia: https://mecoedutna.weebly.com/vision-and-mission.html

Väyrynen, R. (2003), Regionalism: Old and New. International Studies Review Vol. 5 No. 1, 25-51.

Söderbaum, F., \& Shaw, T. M. (2003). Theories of New Regionalism: A Palgrave Macmillan Reader. New York: Palgrave Macmillan.

Lim, E., \& Liu, K.-l. (2018, February 3), Taiwan delegation to promote academic, business links with Philippines. Retrieved from Focus Taiwan: https://focustaiwan.tw/politics/201802030017

News Insider. (2020, April 13), \#TaiwanCanHelp. Retrieved from News Insider: http://newsinsider.ph/2020/04/taiwancanhelp/

MECO/Edu-Connect Training Network in Asia. (n.d.). What We Do. Retrieved from MECO/Edu-Connect Training Network in Asia: https://mecoedutna.weebly.com/what-we-do.html

Dabène, O. (2009). The Politics of Regional Integration in Latin America: Theoretical and Comparative Explorations. New York: Palgrave Macmillan. 
Geducos, A. (2020, April 30), Palace maintains one-China policy stand. Retrieved from Manila Bulletin: https://news.mb.com.ph/2020/04/30/palace-maintains-one-chinapolicy-stand/

Dabu, F. (2019, January 25), UP hosts delegates from Southern Taiwan Universities. Retrieved from University of the Philippines: https://www.up.edu.ph/up-hostsdelegates-from-southern-taiwan-universities/

Funa vs. MECO, G.R. No. 193462 (Supreme Court of the Philippines February 4, 2014).

Lacher, H. (2003), Putting the state in its place: The critique of state-centrism and its limits. Review of International Studies Vol. 29 No. 4 , 521-541.

Knight, J. (2017). Global: Moving from soft power to knowledge diplomacy. In G. Mihut,

P. Altbach, \& H. de Wit, Understanding Higher Education Internationalization: Insights from Key Global Publications (pp. 381-382). Rotterdam: Sense Publishers.

Tadaki, M., \& Tremewan, C. (2013), Re-imagining internationalization in higher education: international consortia as a transformative consortia? Studies in Higher Education 38:3 , 367-387.

Martin, F., \& Griffiths, H. (2012). Power and representation: a post-colonial reading of global partnerships and teacher development through North-South study visits. British Educational Research Journal Vol. 38 No. 6 , 907-927.

Hobson, J. M., \& Seabrooke, L. (2007). Everyday Politics of the World Economy. London: Cambridge University Press.

Hagenmeier, C. (2017). Global: Ensuing equality in higher education partnerships involving unequal universities in divergent contexts. In G. Mihut, P. G. Altbach, \& $\mathrm{H}$. de Wit, Understanding Higher Education Internationalization: Insights from Key Global Publications (pp. 155-158). Rotterdam: Sense Publishers.

MECO/Edu-Connect Training Network in Asia. (2019, October 15). Kindness Hotel unveils PASUC Fellowship Center. Retrieved from MECO/Edu-Connect Training Network in Asia: https://mecoedu-tna.weebly.com/news/kindness-hotel-unveilspasuc-fellowship-center

Chen, C.-c., Hsu, P., \& Liu, K.-1. (2017, December 28), 17 universities have enrollment rate of less than 60 percent. Retrieved from Focus Taiwan: https://focustaiwan.tw/society/201712280009

Huang, A. (2019, November 22), The crisis in higher education runs deep. Retrieved from Taipei

Times:

https://www.taipeitimes.com/News/editorials/archives/2019/11/22/2003726267 